\title{
GRAMSCI E ALTHUSSER COMO CRÍTICOS DE MAQUIAVEL ${ }^{1}$
}

\author{
Danilo Enrico Martuscelli
}

\begin{abstract}
RESUMO
O artigo compara as análises de Antonio Gramsci e Louis Althusser a partir de um objeto de reflexão comum - o pensamento de Nicolau Maquiavel - e, a partir disso, apresenta a teoria da história implícita em cada um. Para cumprir esse objetivo, fazemos a análise em três partes: 1) apresentamos os elementos que conferem unidade às análises de Maquiavel feitas por Gramsci e Althusser, discutindo também suas interpretações da obra maquiavélica; 2) apresentamos os elementos de ruptura entre as análises de Gramsci e de Althusser e, por fim, 3) na tentativa de apresentar uma visão global da relação entre Althusser e Gramsci como críticos do pensamento de Maquiavel, indicamos o que diferencia esses autores em termos de teoria da história. Enquanto Maquiavel possuía uma visão cíclica da história, por acreditar em uma determinada natureza humana, Gramsci recusava qualquer tipo de natureza inata, embora possuísse uma visão teleológica da história, e Althusser, concordando com Gramsci quanto à ausência de uma natureza humana inata, discordava deste último quanto à concepção teleológica, preferindo uma concepção pluricausal, enraizada na concepção de coexistência de modos de produção e na coexistência de mais de duas classes sociais.
\end{abstract}

PALAVRAS-CHAVE: Teoria Política; marxismo; luta de classes; teoria da história; Maquiavel; Gramsci; Althusser.

\section{INTRODUÇÃO}

Este artigo tem como objetivo comparar as análises de Antonio Gramsci e Louis Althusser a partir de um objeto de reflexão comum: o pensamento de Nicolau Maquiavel. A propósito, não pretendemos identificar qual das análises possui a interpretação mais fidedigna ou adequada da obra de Maquiavel; tampouco tencionamos sustentar a idéia de que não é possível entender Gramsci e Althusser sem antes conhecer a fundo o pensamento de Maquiavel. Proceder dessa maneira induzir-nos-ia ao erro de ocultar o corte epistemológico existente entre o pensamento de Maquiavel e as reflexões de Gramsci e Althusser, bem como a legitimar certo tipo de interpretação reducionista que considera possível identificar as "origens" de um pensamento. Partindo do conceito de processo histórico, formulado por essas análises, encontramo-nos em melhores condições de evidenciar as diferenças entre elas.

Maquiavel compreende a história como um movimento cíclico, que varia entre a ordem e a desordem, ou melhor, varia em termos de tempos de duração das formas de convívio entre os homens, uma vez que não haveria como transformar o caráter imutável de certos atributos huma- nos. É certo que Maquiavel não sistematiza teoricamente o que consideraria como um "estado de natureza” humano, à moda de Hobbes, Locke ou Rousseau, mas deixa bastante explícita a sua concepção de natureza humana ao longo de todo $O$ príncipe. De maneira que, para Maquiavel (2004, p. 106), "os homens costumam ser ingratos, volúveis, dissimulados, covardes e ambiciosos de dinheiro". Assim, na tentativa de estabilizar os conflitos gerados por essa natureza humana, Maquiavel lança-se ao desafio de refletir sobre o tipo de ação que um Príncipe deve tomar em diferentes circunstâncias políticas, a fim de garantir a manutenção de seu poder.

Gramsci e Althusser rompem completamente com essa perspectiva cíclica da história e, conse-

\footnotetext{
1 Agradecemos aos colegas Alvaro Bianchi, Andriei Gutierrez, Henrique Amorim, Leandro Galastri e Luciano Martorano, bem como aos dois pareceristas anônimos da Revista de Sociologia e Política, pelos valiosos comentários críticos feitos às versões preliminares deste texto. Obviamente, não pude incorporar todas as idéias e comentários por conta de certas discordâncias teóricas ou por imaturidade e insegurança de minha parte para tratar de algumas questões.
} 
qüentemente, com a idéia de natureza humana fixa e imutável, uma vez que não concebem a existência das sociedades de classes e as relações de poder delas decorrentes como algo natural. Isso, no entanto, não quer dizer que Gramsci e Althusser cheguem aos mesmos resultados no processo de atualização e assimilação do pensamento de Maquiavel. Ao analisar os textos de Althusser, parece-nos impreciso afirmar que eles expressam estritamente uma perspectiva neo-gramsciana, como pretendem Holden e Elden (2005). Talvez seja mais adequado sustentar que, para "trabalhar" sobre a obra de Maquiavel (matéria-prima), Althusser tenha tomado as reflexões de Gramsci como instrumento de produção teórica. Tal hipótese nos leva a problematizar a perspectiva analítica que sustenta a simples identidade entre as duas interpretações da obra de Maquiavel, e a evidenciar o processo complexo de "assimilação profunda” dessa obra, que pode expressar tanto a capacidade de Althusser de propor novos argumentos favoráveis a algumas das teses elaboradas pela análise de Gramsci e, em certo sentido, de desenvolvê-las teoricamente - o que resultaria numa formulação neo-gramsciana -, quanto pode demonstrar a competência daquele autor para criticar certas teses gramscianas, ao sistematizar seus limites internos e apresentar conceitos alternativos aos já formulados por Gramsci - o que poderia resultar numa formulação original ou simplesmente distinta ${ }^{2}$. Cabe-nos, ainda, detectar, nesse processo de assimilação da obra de Maquiavel, quais dos dois desenvolvimentos, de unidade ou de ruptura em relação às reflexões de Gramsci, são predominantes na análise de Althusser.

Para cumprir esse objetivo, propomo-nos a decompor nossa análise em três partes principais: na primeira, procuraremos apresentar os elementos que conferem unidade às análises de Gramsci e Althusser; na segunda, avançaremos na discussão sobre os elementos de ruptura entre tais análises; por fim, na tentativa de apresentar uma visão global da relação entre Althusser e Gramsci como críticos do pensamento de Maquiavel, procuraremos apresentar o que os diferenciam em termos de definição de uma teoria da história.

\footnotetext{
2 Emprestamos de Saes (1998a, p. 12) a idéia de “assimilação profunda”.
}

\section{ALTHUSSER LEITOR DE MAQUIAVEL: UMA ABORDAGEM NEO-GRAMSCIANA?}

\section{II.1. A política no posto de comando}

O significado da política e o lugar que esta ocupa na vida social são dois aspectos fundamentais debatidos por Gramsci e Althusser à luz das reflexões de Maquiavel. Em uma das passagens dos Cadernos, Gramsci (2000, p. 13) observa que: "O caráter fundamental do Príncipe é o de não ser um tratado sistemático, mas um livro 'vivo', no qual a ideologia política e a ciência política fundem-se na forma dramática do mito" - o que significa dizer que Maquiavel não se propôs a formular um tratado sistemático sobre a política, ou melhor, para ele, o mais importante era descobrir "la verità effetuale della cosa", concebida não como algo estático, imóvel ou imaginário, mas como "uma relação de forças em contínuo movimento e mudança de equilíbrio", como conhecimento objetivo da coisa. Afinal, os príncipes, como todos os homens, estão expostos a circunstâncias aleatórias do destino, que Maquiavel chama de fortuna, ou sorte. A fortuna ou sorte pode ser mais ou menos bem aproveitada dependendo das qualidades de cada um; da capacidade de cada um de agir no momento correto e, portanto, o Príncipe pode conduzir melhor ou pior as oportunidades que se lhe apresentem conforme seja mais ou menos politicamente virtuoso, conforme saiba agir com maior ou menor perspicácia sempre mantendo o objetivo da consolidação e reprodução de seu poder, em conseqüência, do poder de Estado.

De acordo com Gramsci, Maquiavel não buscou tratar da natureza e das leis da política nos seus escritos. Assim, não é possível extrairmos desses escritos uma teoria da política. Sob esse prisma, Maquiavel não pode ser concebido como um cientista político ou mesmo como um "político em geral”, como fazia a tradição aristotélica e platônica, uma vez que seus escritos não têm o alcance nem a pretensão de explicar a política em todos os tempos.

Ao refletir sobre a questão da política na obra de Maquiavel, Gramsci (2000, p. 29) considera que o mais procedente é considerar esse filósofo “como expressão necessária de seu tempo e como estreitamente ligado às condições e exigências de sua época [...]." Ou ainda: "Maquiavel é um homem inteiramente de seu tempo e sua ciência po- 
lítica representa a filosofia da época que tende à organização das monarquias nacionais absolutas, a forma política que permite e facilita um novo desenvolvimento das forças produtivas burguesas" (idem, p. 30).

Embora, nessa passagem, Gramsci possa sugerir que Maquiavel tenha sido um cientista político, tal entendimento, literal, deve dar lugar ao de que se trata de uma frase de efeito. Levar a tese da positividade da ciência política às últimas conseqüências na obra de Gramsci resultaria numa incongruência em face de sua própria formulação de que não é possível tratar a política como atividade autônoma em relação às demais atividades sociais. Nessa problemática, a política não se singulariza ou possui características que lhe são próprias. Assim, ao contrário do que sugere Coutinho (2003), não entendemos que Gramsci tenha uma visão positiva da ciência política, mas da ação política fundadora do momento dos interesses universais, também denominado momento éticopolítico.

Para Gramsci, Maquiavel não pode ser considerado um "tratadista sistemático", mas um "homem de ação", um "homem de partido”, um "homem de paixões poderosas”, um "político em ato", ou melhor, Maquiavel teria procurado resolver problemas referentes à "grande política”, às mudanças estruturais, especificamente, à fundação e a consolidação do Estado nacional italiano. Nesse sentido, a continuidade do Papado necessariamente levaria a Itália à condição de não-Estado. Isto é, enquanto a própria religião não deixasse de ser política do Papa para tornar-se uma "política" do Estado, a Itália não teria condições de compor um Estado nacional. Gramsci procura demonstrar, portanto, que Maquiavel não nega a religião pura e simplesmente, mas desloca-a da condição dominante para a condição subordinada em relação à política, a fim de construir o seu objetivo maior que é a fundação do Estado nacional italiano. Gramsci também entende que a questão técnicomilitar não pode ser compreendida de maneira isolada, visto que, na obra de Maquiavel, ela é concebida como uma questão subordinada à "construção política”. Ou seja, a questão técnico-militar não se constitui o cerne da análise de Maquiavel, formulando-se como questão subordinada à política. Enfim, Gramsci evidencia, a partir da obra de Maquiavel, que a política deve ser concebida como atividade que subordina a moral, a religião e a questão militar ${ }^{3}$ e, justamente por isso, não pode ser considerada uma atividade autônoma.

Gramsci enfatiza o fato de Maquiavel diferenciar-se de seus antecessores - cujas análises são marcadas por um viés idealista - por colocar a política no lugar dominante das relações com outras esferas da vida social. Isso quer dizer que a primazia da política em relação à religião e à questão técnico-militar, ressaltada por Gramsci na análise da obra de Maquiavel, coloca sua interpretação num terreno bastante distinto da análise de Croce. Este teria instrumentalizado o conceito de política, ao conferir a ele um sentido de neutralidade, sugerindo, assim, uma disjunção absoluta entre pensamento - ou, mais precisamente, filosofia - e atividade sócio-política - isto é, política (FONTANA, 1993). Quando define, pois, a autonomia da política em termos relativos, e não em termos de autonomia absoluta em relação à moral, à religião, à questão técnico-militar, Gramsci observa que a política deve ser pensada numa relação dialética ou de identidade com a filosofia (KANOUSSI, 2003).

É a partir dessa compreensão da política que Gramsci detecta a ruptura de Maquiavel com o feudalismo e o Renascimento. Como ele observou no diálogo com o Cardeal Rouen, que afirmara que os italianos não entendiam de guerra, a res-

3 No tocante à questão militar, é importante salientar que uma das principais dificuldades divisadas por Maquiavel, tanto em O príncipe como em A Arte da Guerra, no sentido da consolidação do poder nos principados é a inexistência de exércitos nacionais permanentes e profissionais. Nos principados italianos é comum, à época, a contratação de milícias para objetivos específicos como golpes ou contragolpes, milícias que são imediatamente desmobilizadas apenas atingindo o objetivo do príncipe contratante, ficando este então desguarnecido militarmente. Isso pra não falar das traições às vezes empreendidas pelo próprio comandante da milícia contratada, usurpando ele próprio o lugar do inimigo derrubado. É a partir dessa constatação que Maquiavel dá início a uma das mais importantes questões da Ciência Política moderna e do poder de Estado: “[...] as forças com as quais um príncipe preserva seu Estado são ou próprias ou mercenárias, ou auxiliares ou mistas. As mercenárias e as auxiliares são inúteis e perigosas. Se alguém mantiver seu Estado apoiado nessa classe de forças, nunca haverá de estar seguro; não se unem aos príncipes, são ambiciosas, indisciplinadas, desleais, insolentes, para com os amigos e covardes diante dos inimigos, não têm o temor a Deus nem confiam nos homens, e o príncipe apenas adia sua ruína enquanto adia o ataque" (MAQUIAVEL, 2004, p. 85-86). 
posta de Maquiavel - de que os franceses não entendiam de Estado - não pode ser tomada no sentido literal, uma vez que não se presta a deduções científicas, antes se tratando de uma "frase de espírito, de uma réplica de efeito imediato": "Naquele seu diálogo com o Cardeal de Rouen, ele fez 'política' prática e não 'ciência política', porque, segundo ele, se o fortalecimento do Papa era prejudicial à 'política externa' francesa, era mais prejudicial ainda à política interna italiana" (GRAMSCI, 2000, p. 217).

Para Gramsci, faz-se necessário o deslocamento da política da posição subordinada para a posição dominante em relação às demais esferas sociais, para tornar possível a fundação do momento "ético-político", que ultrapassa o nível dos interesses imediatos e particulares e que, portanto, constitui o momento da liberdade, dos interesses universais. Essa tarefa deveria ser concebida tendo-se em vista as relações de força atuais - o que leva Gramsci, na análise da obra de Maquiavel, a relevar os aspectos internos e externos que dificultavam a construção da unidade nacional do Estado italiano, a saber: as divisões e conflitos internos e a vulnerabilidade aos ataques e ameaças externos. Enfim, em Gramsci, a política, ao ocupar o lugar dominante na vida social, não comporta a idéia de neutralidade técnica, que separa de modo radical filosofia e política, visto que todas as práticas sociais estão, de modo direto e indireto, sob influência da política. No entanto, ao enfatizar a historicidade dos processos sociais e colocar a política no posto de comando, Gramsci parece dar pouca atenção aos obstáculos estruturais que impedem a emergência de uma prática política efetivamente revolucionária.

Em concordância com Gramsci, Althusser sustenta a idéia segundo a qual não há uma teoria da política em Maquiavel. Para Althusser, Maquiavel não se interessa pela natureza das coisas. Isso significa que os elementos teóricos, ainda que existentes na obra de Maquiavel, não se articulariam sob a forma de uma teoria. Eles estariam dispostos sob a forma de fragmentos ou, ainda, estariam voltados para o conhecimento da prática política: “A colocação do problema da prática política está no coração de tudo: todos os elementos estão, portanto, dispostos [...] em função desse problema político central [o problema político da prática concreta da formação e da constituição da unidade nacional]” (ALTHUSSER, 1997, p. 59).
Nessa perspectiva, Maquiavel é compreendido como o teórico da conjuntura, como o primeiro a pensar na conjuntura, ou ainda, a pensar no conceito de conjuntura como caso singular. Mas, pensar na conjuntura, pensar sob a categoria conjuntura, não tem o mesmo significado que pensar sobre a conjuntura, pois, segundo Althusser, Maquiavel não estabelece reflexões sobre um conjunto de dados concretos: "Pensar sobre a conjuntura é literalmente se submeter ao problema que produz e impõe seu caso: o problema político da unidade, a constituição da Itália em Estado nacional. É necessário aqui reverter os termos: Maquiavel não pensa o problema da unidade nacional em termos de conjuntura; é a própria conjuntura que coloca negativamente, mas de modo objetivo, o problema da unidade nacional italiana" (idem, p. 61).

Por esses motivos, expressa-se na obra de Maquiavel a ruptura com as tradições aristotélica e platônica. A remissão que ele faz à Antiguidade não tem o propósito de recuperar as "teorias filosóficas da política”, mas a história concreta, da prática política concreta, da política na Antiguidade. Isto é, a Antiguidade que importa para Maquiavel é a "Antiguidade da política". Nesse ponto, poderíamos assinalar que, de prisma similar ao de Gramsci, Althusser concebe as referências à história da Antiguidade, presentes na obra de Maquiavel, como analogia histórica, ressaltando, contudo, a possibilidade de extrair dessa obra uma teoria da conjuntura ${ }^{4}$.

O lugar subordinado que a religião e a técnica militar têm em relação à política na obra de Maquiavel justificaria, para Althusser, o caráter antifeudal dessa obra. Uma vez que Maquiavel coloca a unidade nacional italiana como objetivo a concretizar, as formas feudais existentes seriam tratadas como incompatíveis com esse objetivo político. Nesse outro tópico, mais uma vez encontramos uma aproximação entre as análises de Althusser e Gramsci. Observamos, no entanto, que, na análise de Althusser, as condições objetivas para a constituição da unidade nacional imperam sobre as condições subjetivas, ou ainda, a constituição dessa unidade não pode ocorrer como simples ato de vontade, como mero "otimismo da vontade” dos agentes - digo: das vanguardas -

\footnotetext{
4 Aprofundaremos a discussão a respeito da teoria da conjuntura mais adiante.
} 
que defendem essa causa. Não é por acaso que, em sua auto-biografia, Althusser negue o uso das expressões "pessimismo da inteligência” e "otimismo da vontade", empregadas por Gramsci, e conclua, de modo contundente, o seguinte: [...] acredito na lucidez da inteligência e no primado dos movimentos populares sobre a inteligência. A esse preço, porque ela não é a instância suprema, a inteligência pode seguir os movimentos populares, inclusive e antes de tudo a fim de evitar que esses tornem a cair nas aberrações passadas e a fim de ajudá-los a encontrar formas de organização realmente democráticas e eficazes. Se podemos conceber, apesar de tudo, alguma esperança em ajudar a desviar o curso da história, aí está ela, e só aí. Em todo caso, não nos sonhos escatológicos de uma ideologia religiosa com a qual estamos todos morrendo. Mas, aqui, eis-nos em plena política” (ALTHUSSER, 1992, p. 200).

Quando nos referimos aqui ao primado das condições objetivas sobre as condições subjetivas, chamamos a atenção para a idéia de que, para Althusser, não é uma consciência adjudicada, importada de fora, que fará que as massas populares, tomadas como amorfas, se esclarecem sobre o melhor mundo para viver-se. Utilizando uma metáfora empregada por Mao, diríamos que a lucidez da inteligência não deve tencionar o arco e disparar a flecha, mas sim tencionar o arco e indicar uma direção, orientar a prática revolucionária das massas populares, cabendo a elas próprias a iniciativa "de tirar os ídolos e derrubar os templos das virgens mártires e os portais comemorativos em honra das viúvas castas e fiéis: é errado que outros o façam por eles” (TSÉ-TUNG, 1968, p. 45).

II.2. A unidade profunda: O príncipe e os Discursos

A existência de uma unidade profunda entre as obras O príncipe e os Discursos de Maquiavel é outra tese compartilhada pelas análises de Gramsci e Althusser. Porém, a forma de apreendê-la é distinta nessas análises.

Gramsci sustenta, nos Cadernos do cárcere, que essas duas obras de Maquiavel não podem ser concebidas de modo separado. Segundo ele, ainda que se possa tratar $O$ príncipe como o momento da autoridade ou da força e os Discursos como o momento da hegemonia ou do consenso, essa distinção não pode ser considerada uma oposição de princípio, mas uma distinção metodológica. Tanto num texto como no outro, os momentos de coerção e consentimento estão presentes, ou melhor: “[...] não há oposição de princípio entre principado e república, mas se trata sobretudo da hipóstase dos dois momentos de autoridade e universalidade" (GRAMSCI, 2000, p. 22). Para elucidar essa questão, Gramsci retoma da obra $O$ príncipe a metáfora da natureza dúplice do centauro: a que se refere à natureza "ferina e humana, da força e do consenso, da autoridade e da hegemonia, da violência e da civilidade, do momento individual e do momento universal” (idem, p. 33) ${ }^{5}$.

Além da unidade dos momentos de autoridade e de consentimento, outra tese defendida por Gramsci é a da existência de uma unidade das duas obras principais de Maquiavel. Ou seja, a existência de um problema político comum: a constituição do Estado nacional italiano como condição imprescindível para a superação dos conflitos internos e das ameaças de invasão externa existentes na Itália ${ }^{6}$. Assim, as relações de forças vigentes na conjuntura histórica precedente à unificação nacional italiana assumem uma importância vital nas reflexões de Maquiavel. Isso leva Gramsci a sustentar a tese de que para a solução dos conflitos existentes numa sociedade cindida como a italiana não se deve considerar apenas a articulação entre força e consenso, mas também entre os fatores endógenos e exógenos, tendo primazia, nesse caso, a superação dos problemas internos o que somente é possível com a constituição do Estado nacional italiano.

Althusser extrai de Gramsci a tese da indissociabilidade das obras $O$ príncipe e os Discursos, desenvolvendo, contudo, idéias e argumentos distintos. Para Althusser (1997), há duas formas, articuladas entre si, de pensar a unidade entre as duas obras: por um lado, como unidade do objeto de reflexão; por outro lado, como unidade do problema político colocado.

\footnotetext{
5 Fontana (1993, p. 129-132) também salienta a inexistência de uma contradição entre o momento da autoridade e do indivíduo e o momento do universal e da liberdade nos textos de Maquiavel.

6 É interessante observar que, segundo Holden e Elden (2005), em análises como as de Foucault, a existência desse problema político comum nessas duas obras de Maquiavel sequer é mencionada, ou ainda, os Discursos nem sempre
} são matéria de reflexão teórica. 
Para ele, tanto em $O$ príncipe quanto nos Discursos o objeto de análise é a prática política do Príncipe. Essa consideração é particularmente importante, pois, segundo esse autor (1997), fazse necessário distinguir o espaço da teoria pura ou geral do espaço da prática política. A obra de Maquiavel não se enquadra, segundo Althusser, no desenvolvimento do primeiro espaço, pois o filósofo florentino não desvenda as leis e a natureza da política, não sistematiza, portanto, uma teoria da política. Se assim fizesse, seria necessário, ao menos, que a análise de Maquiavel não refletisse sobre o sujeito da prática política. Ou melhor, conforme Althusser (1997), o espaço da teoria só faz sentido se não houver sujeito, o que significa que, nesse espaço, a verdade vale para todo sujeito possível. Por oposição, o espaço da prática só tem sentido se houver o sujeito da prática política. Dada a existência do sujeito da prática política (o Príncipe), o conceito de conjuntura presente na obra de Maquiavel encontra-se em estado prático, ou seja, aplicado na análise, mas não refletido, formulado teoricamente.

Como observa Althusser, nas duas obras principais de Maquiavel o sujeito da prática política é o mesmo: o Príncipe. É, portanto, a prática política do Príncipe, a prática política de "um indivíduo de exceção, dotado de virtù, que, partindo do nada ou de alguma coisa, saberá mobilizar as forças adequadas para unificar a nação italiana sob sua direção” (ALTHUSSER, 1997, p. 62). O príncipe é a forma da solução de um problema político anunciado por Maquiavel: o problema da unidade nacional italiana. Assim, a oposição monarquia-república freqüentemente utilizada para ilustrar a oposição entre $O$ príncipe e os Discursos é incongruente com o conteúdo do conjunto dessas obras. Althusser observa que Maquiavel discute o começo, a fundação de um Estado durável, a constituição do Estado nacional italiano, mas de modo algum preconiza uma tipologia das formas de governo (monarquia ou república) que pudesse aplicar-se em todos os tempos históricos. Isto é, não desenvolve "uma classificação prévia dos governos, uma tipologia dos governos, clássica desde Aristóteles, que considera as diferentes formas de governo, sua normalidade, sua patologia" (ALTHUSSER, 1998, p. 314; sem grifos no original). Maquiavel coloca um problema político - a unificação da nação italiana - e define uma tática histórica, ou seja, um instrumento que possa forjar essa unidade: o Estado nacional. Noutros ter- mos, o objetivo de Maquiavel, segundo Althusser, não é o de elaborar "a teoria do Estado nacional existente na França ou na Espanha no tempo em que viveram sob a forma da monarquia absoluta, mas de colocar a questão política das condições da fundação de um Estado nacional num país sem unidade, a Itália” (idem, p. 315; sem grifos no original).

Para negar a suposta oposição entre monarquia e república na obra de Maquiavel, Althusser distingue dois momentos decisivos da constituição de um Estado - o que lhe permite colocar sob a forma teórica o conceito de conjuntura: “1. O momento do começo absoluto, que pode ser apenas o feito de um único, de um 'indivíduo sozinho'. Mas que é instável, pois pode no limite oscilar tanto do lado da tirania quanto do lado de um Estado verdadeiro. [...] 2. o segundo momento é o da duração, que só pode ser assegurada por uma dupla operação: a dotação de leis e a saída da solidão, isto é, o fim do poder absoluto de um só (ALTHUSSER, 1997, p. 119-120; sem grifos no original).

Nessa passagem, é interessante notar a proximidade das reflexões de Althusser com as de Bettelheim, quando este procura definir a "estrutura da conjuntura" e conceber diferentes tipos de periodização. Vejamos qual sentido esse autor dá ao termo "fase": "Parece justificado reservar o termo 'fase' para designar os dois momentos do desenvolvimento de uma formação social, a saber: 1) o de seu início, quer dizer, a fase de transição no sentido estrito, que é também o de uma não correspondência específica entre forças produtivas e relações de produção [...]. E 2) a fase da reprodução ampliada da estrutura de produção, que pode ser o objeto de uma análise sincrônica e que é caracterizada por uma dinâmica própria” (BETTELHEIM, 1969, p. 28; sem grifos no original).

Caso aplicássemos essa definição de fase à obra de Maquiavel, poderíamos dizer que se a monarquia absoluta - e, portanto, um poder único, centralizado, mas não arbitrário - é o momento do começo absoluto da fundação de um Estado, que só depende do indivíduo (o Príncipe), a república representa o momento da duração, da consolidação do Estado nacional, do fim da solidão absoluta do reformador ou do fundador, da dotação de leis. Assim, monarquia e república, em vez de regimes opostos, poderiam ser pensadas 
como momentos distintos (fases), articulados entre si e decisivos na constituição e durabilidade do Estado nacional ${ }^{7}$.

Embora Althusser desenvolva argumentos favoráveis à argumentação de Gramsci no tocante ao significado e ao lugar da política na vida social, assim como ratifique a tese da unidade entre as obras O príncipe e os Discursos, de Maquiavel vislumbrando, não obstante, resultados diferentes -, não podemos verificar a mesma convergência no que se refere às questões analisadas a seguir. Aqui nos parece que as aproximações entre um e outro autor são ainda mais tênues.

\section{ALTHUSSER E GRAMSCI: DUAS LEITU- RAS DE MAQUIAVEL?}

\section{III.1. Intelectual de seu tempo ou a solidão de Maquiavel}

Um dos pontos de desacordo entre as análises de Gramsci e Althusser é o lugar que a obra de Maquiavel ocupa na história do pensamento político.

No início do Caderno 13, Gramsci chama a atenção para o fato de que a obra $O$ príncipe é um "livro vivo", podendo ser concebida como a exemplificação histórica do "mito" soreliano, isto é, como expressão da "ideologia política que se apresenta como uma criação da fantasia concreta que atua sobre um povo disperso e pulverizado para despertar e organizar sua vontade coletiva” (GRAMSCI, 2000, p. 13-14). Ou como Gramsci salienta em outra passagem: "Pode-se [...] dizer que Maquiavel propôs-se educar o povo, mas não no sentido que habitualmente se dá a esta expressão ou, pelo menos, lhe deram certas correntes democráticas. Para Maquiavel, 'educar o povo' pode ter significado apenas torná-lo convencido e consciente de que pode existir uma única política, a realista, para alcançar o fim desejado e que, portanto, é preciso cerrar fileiras e obedecer exatamente àquele Príncipe que emprega tais métodos para alcançar o fim, porque só quem almeja o fim, almeja os meios adequados para alcançá-lo. Em tal sentido, a posição de Maquiavel deve ser aproximada daquela dos teóricos e dos políticos da filosofia da práxis, que também procuram cons-

${ }^{7}$ Voltaremos à discussão sobre a forma instável e duradoura do desenvolvimento de uma formação social no último tópico deste artigo. truir e difundir um 'realismo' popular, de massa, e tiveram de lutar contra uma forma de 'jesuitismo' adaptada aos novos tempos” (idem, p. 307).

Aqui Gramsci opera com a distinção entre os pares intelectual tradicional e intelectual orgânico ou intelectual cosmopolita ${ }^{8} \mathrm{e}$ intelectual nacionalpopular, contrapondo, respectivamente, a atividade diplomática, de preservação das relações sociais existentes, de distanciamento em relação às massas populares - o que corresponderia a mantêlas numa situação primitiva de conhecimento - e a atividade política, de transformação das relações sociais existentes, de relação educacional dialética com o povo - o que implicaria o ato de educar e ser educado pelo povo ${ }^{9}$. Assim se contribuiria para a criação de uma reforma intelectual e moral, possibilitando às massas populares atingirem uma concepção de mundo que deslocasse a concepção dominante para uma posição subordinada nas novas relações sociais estabelecidas ${ }^{10}$. Nessa perspectiva, Maquiavel representaria a figura do intelectual orgânico e nacional-popular de sua época.

Cabe ressaltar, contudo, que Maquiavel, segundo Gramsci, não pode ser concebido como um intelectual que tomava como exemplo exclusivamente os problemas italianos, uma vez que eram a França e a Espanha os exemplos mais visíveis de possibilidade da unidade estatal territorial. É a partir de uma "comparação elíptica” entre, de um lado, a Itália, e, de outro, a França e a Espanha, que Maquiavel, segundo Gramsci, deduz as regras para um Estado forte em geral e o Estado italiano em particular. Com isso, não podemos conceber Maquiavel como um intelectual que pensa

\footnotetext{
8 Em Gramsci, é possível identificar uma diferença fundamental entre o intelectual com função cosmopolita - ao qual é atribuído valor positivo, uma vez que esse intelectual tem a capacidade de articular os elementos internos e externos para resolver o problema da unidade do Estado nacional, vinculando-se diretamente com a educação do povo - e o intelectual cosmopolita - ao qual é conferido valor negativo devido ao fato de este ater-se aos fenômenos exclusivamente extranacionais, descurando da incorporação das massas populares na resolução ou tomada de decisões políticas.

${ }^{9}$ Idéia provavelmente retomada da III tese sobre Feuerbach em que Marx aventa a necessidade de o educador ser educado.

10 Ver Fontana (1993), em especial o cap. 3, Renaissance and Reformation.
} 
os problemas italianos e as formas de superá-los como reflexo da conjuntura exclusivamente italiana. Gramsci, numa passagem dos Cadernos, chega a afirmar que Maquiavel não só pensou os problemas extra-italianos, como também serviu aos Estados absolutos em formação: “[...] Maquiavel serviu realmente aos Estados absolutos em sua formação, porque tinha sido a expressão da 'filosofia da época', européia mais do que italiana” (GRAMSCI, 2000, p. 228).

Nessa passagem, Gramsci evidencia o caráter e a função cosmopolita dos escritos de Maquiavel. Tal questão é retomada com todo vigor em outra passagem, quando Gramsci trata especificamente da função cosmopolita dos intelectuais italianos: "Os intelectuais italianos eram funcionalmente uma concentração cultural cosmopolita, eles acolhiam e elaboravam teoricamente os reflexos da mais consistente e autóctone vida do mundo não italiano. Vê-se essa função também em Maquiavel, embora Maquiavel tente dirigi-la para fins nacionais (sem êxito e sem continuadores em número apreciável): com efeito, o Príncipe é uma elaboração dos eventos espanhóis, franceses, ingleses no empenho pela unificação nacional, unificação que na Itália, não tem forças suficientes e nem interessa muito.” (GRAMSCI, 1999, p. 429-430). Ou ainda: Maquiavel "é o teórico do que ocorre fora da Itália, não de eventos italianos” (GRAMSCI, 2000, p. 342).

Nessas notas, Gramsci caracteriza Maquiavel como um intelectual com função cosmopolita. Nesse sentido, a obra de Maquiavel pode ser concebida como a expressão do modo de pensar específico dos intelectuais da época em que viveu, os quais estavam atentos aos eventos extra-italianos. Ainda que se considere sua obra como de ruptura, foi o fato de seu fazer intelectual estar ligado, como o de outros tantos intelectuais italianos, aos acontecimentos extra-italianos que the permitiu colocar o problema político concreto da unificação nacional italiana.

A defesa que Maquiavel faz da unificação nacional da Itália parece ser resultado de um certo “otimismo da vontade”, já que a situação concreta italiana que ele mesmo descreve só pode ser pensada nos termos de um "pessimismo da inteligência”. Portanto, para analisar a obra de Maquiavel, Gramsci não toma como referência apenas a ruptura desse autor com a tradição dos tratados sistemáticos da Antiguidade, mas leva em consideração o quadro da intelectualidade italiana no período vivido por Maquiavel.

Seguindo a análise de Gramsci, afirmaríamos que Maquiavel colocou como tarefa a ser resolvida a fundação do Estado nacional italiano, pois tomou como referência os exemplos da França e da Espanha. Dessa maneira, Maquiavel não pode ser entendido como um visionário, formulando idéias inteiramente novas, sem par na história da humanidade. Ao contrário, Maquiavel era um homem de seu tempo, que, ao se colocar na posição de intelectual com função cosmopolita, que pensa os problemas extra-italianos, propunha-se resolver as questões de ordem interna, mesmo que para isso tivesse que realizar seu intento sob a forma de um manifesto político, ou melhor, anunciar os modos de superar os obstáculos que se impunham à situação política italiana de seu tempo. Sendo assim, embora as condições materiais de resolução do problema da unidade nacional na Itália ainda não existissem, já estavam em vias de existir. É possível concluir, então, que, para Gramsci, Maquiavel militava em prol de um problema que a humanidade - italiana - necessariamente resolveria. Há, portanto, em Gramsci, a afirmação de uma visão teleológica do processo histórico que se resume na identificação de um trajeto a ser seguido pela sociedade italiana em direção a um fim, traduzindo-se, na problemática de Maquiavel, como a constituição da unidade italiana, e, na análise de Gramsci, como a construção do momento éticopolítico ${ }^{11}$.

Quando procura situar a obra de Maquiavel diante dos autores e tradições filosóficas que trataram da questão da política, Althusser considera-a imersa na solidão. Mas o que significa essa solidão? Ela expressa o caráter de "começo de algo sem precedente” da obra de Maquiavel. A fórmula que consagra esse começo está apresentada de modo visível em seus escritos, quando Maquiavel afirma que é mais justo ir à verdade efetiva da coisa que à sua imaginação. Segundo Althusser, o discurso de Maquiavel pode ser considerado um começo sem precedente ou mesmo uma ruptura, pois ele condena "não apenas os discursos edificantes, religiosos e morais ou estéticos dos Humanistas de séquito, e mesmo os Humanistas radicais, não apenas os sermões revolucionários

11 Voltaremos a essa questão mais adiante. 
de um Savonarola, mas também toda a tradição da ideologia cristã, e todas as teorias políticas da Antiguidade" (MAQUIAVEL, 1997, p. 47).

Maquiavel não pode ser classificado, de acordo com Althusser, como pertencente à tradição do direito natural, visto que sua obra não trata de um Estado já formado, mas de uma tarefa a ser cumprida: a unidade da nação italiana. Nesse sentido, ao buscar o conhecimento da prática política, Maquiavel traz-nos uma contribuição inovadora para o estudo da política, não podendo ser igualada à tradição teórica anterior aos seus escritos - a qual tratava das leis de governo; uma tradição moralizante, religiosa e idealista do pensamento político -, nem à tradição teórica posterior aos seus escritos - a qual iria tratar dos problemas de direito de um Estado nacional já constituído, ou melhor, a tradição da nova filosofia do direito natural. Como Althusser destaca: "Maquiavel fala da monarquia absoluta existente na França e na Espanha, mas como exemplo e argumento para tratar de um objeto completamente diferente; para tratar da constituição de um Estado nacional na Itália: ele fala de um acontecimento a se realizar (ALTHUSSER, 1998, p. 319; sem grifos no original).

Pelo fato de não poder situar a obra de Maquiavel em uma tradição teórica ou mesmo classificá-la, Althusser sustenta a idéia de que Maquiavel encontra-se na solidão: "Maquiavel está sozinho porque ficou isolado, ficou isolado porque, se se discutiu ininterruptamente seu pensamento, não se refletiu sobre o mesmo" (idem, p. 318; sem grifos no original). Ou seja, a obra de Maquiavel não teria sido assimilada, no sentido forte do termo. Assim, se Gramsci integra o pensamento de Maquiavel à perspectiva do "historicismo absoluto" - o que o leva a conceber o filósofo florentino como um "intelectual de seu tempo" e a operar com a problemática do otimismo da vontade e do pessimismo da inteligência , na análise de Althusser não há espaço para tal perspectiva. Dito de outra maneira, a excepcionalidade da obra de Maquiavel não se encontra em seu vínculo com a filosofia da época em que viveu, ou ainda em sua atividade política como filósofo que lida com os problemas extraitalianos, mas situa-se no seu próprio conteúdo de uma obra que está imersa na solidão, à medida que rompe com a tradição filosófica pretérita e não encontra par na filosofia que a sucede.

\section{III.2. A vanguarda revolucionária ou o movimento de massas}

As relações entre partido ou direção, de um lado, e base ou massas, de outro, são outros aspectos abordados pelas análises de Gramsci e Althusser à luz do pensamento de Maquiavel. Aqui, uma vez mais, observam-se elementos de ruptura entre as duas abordagens.

De acordo com Gramsci, o Príncipe idealizado por Maquiavel (o condottiero ideal) não existe na realidade histórica, sendo apenas invocado nos últimos capítulos da obra na figura de César Bórgia (o condottiero "realmente existente"). Isso significa que, a despeito de Maquiavel ter, ao longo de toda a sua obra, descrito o Príncipe com certo distanciamento científico, no final ele "se fez povo”. Para Gramsci, portanto, a co-existência do condottiero ideal e de um condottiero real, na obra $O$ príncipe, revela muito menos uma contradição interna do texto de Maquiavel que uma preocupação deste com o “dever ser”, daí advindo o estilo de manifesto utópico dessa obra.

Na condição de "homem de partido", de "paixões poderosas", Maquiavel deseja criar novas relações de força. Nesse sentido, Gramsci chama a atenção para o fato de que essa questão do "dever ser” não pode ser tratada como um simples problema moral: "trata-se de ver se o 'dever ser' é um ato arbitrário ou necessário, é vontade concreta ou veleidade, desejo, miragem. O político em ato é um criador, um suscitador, mas não cria a partir do nada nem se move na vazia agitação de seus desejos e sonhos. Toma como base a realidade efetiva: mas o que é esta realidade efetiva? Será algo estático e imóvel, ou, ao contrário, uma relação de forças em contínuo movimento e mudança de equilíbrio? Aplicar a vontade à criação de um novo equilíbrio das forças realmente existentes e atuantes, baseando-se naquela determinada força que se considera progressista, fortalecendo-a para fazê-la triunfar, significa continuar movendo-se no terreno da realidade efetiva, mas para dominá-la e superá-la (ou contribuir para isso). Portanto, o "dever ser" é algo concreto, ou melhor, somente ele é interpretação realista e historicista da realidade, somente ele é história em ato e filosofia em ato, somente ele é política" (GRAMSCI, 2000, p. 35).

Assim, não se pode atribuir ao "dever ser" de Maquiavel o mesmo sentido revolucionário empregado por Marx n'O manifesto comunista, vis- 
to que "Maquiavel jamais diz que pensa em, ou propõe-se ele mesmo, mudar a realidade, mas visa apenas concretamente a mostrar como deveriam operar as forças históricas para se tornarem eficientes" (idem, p. 36). Ainda que pese a fórmula revolucionária da unidade da nação italiana, de acordo com Gramsci, Maquiavel compreende-a de maneira utópica, uma vez que a situação concreta italiana não reunia as condições materiais para a constituição do Estado nacional, ou seja, a tarefa política defendida por Maquiavel é inexeqüível por não estar vinculada às condições materiais realmente existentes na Itália de seu tempo, quando o desenvolvimento das forças produtivas não havia tornado-se ainda um obstáculo às relações sociais de produção existentes.

Para Gramsci, o caráter utópico do texto revela-se quando Maquiavel "faz-se povo", ou seja, quando delega a um indivíduo desconhecido - o Príncipe, portador de características excepcionais - a posição de sujeito revolucionário. No entanto, é necessário observar que a referência d'O príncipe é de extrema importância para a elaboração do conceito de moderno Príncipe, de partido revolucionário, para a realidade efetiva da Itália dos anos de 1930. É o sujeito revolucionário que fornecerá condições para a criação em ato do momento ético-político e da sociedade regulada. Trata-se de uma importante reflexão sobre a relação entre partido revolucionário e massas populares. Isso leva Gramsci à crítica da tradição elitista do pensamento político italiano - avessa à participação política das massas -, à crítica da oposição entre teoria e prática política e à defesa de um partido que consiga fazer-se povo: o moderno Príncipe ${ }^{12}$.

12 No que se refere ao tratamento que Gramsci dá ao partido político revolucionário talvez fosse interessante indicar aqui - ainda que de modo provisório e precário duas ausências em seus escritos que podem ter implicações teóricas e políticas de grande monta. A primeira delas refere-se à ausência de reflexão sobre a possibilidade de um pluralismo partidário socialista. Coutinho (1999, p. 170171) sustenta que na caracterização do partido político como "síntese" ou "mediação" da vontade coletiva, Gramsci não explicita que essa "síntese” ou “mediação" pode ser realizada por mais de um partido - o que, em nosso entender, parece indicar que Gramsci sustenta o sistema de partido único como expressão da vontade coletiva. Ainda que Gramsci (2002, p. 140-141) admita a existência de mais de um partido, quando se reporta à possibilidade de exercício da hegemonia do partido dos grupos dominantes sobre o partido dos grupos subalternos, isso não significa que essa
A tese de Gramsci de que $O$ príncipe é um "manifesto utópico revolucionário" é retomada por Althusser (1997, p. 67), que entende que essa obra tem a propriedade de ser "um chamado passional à solução política que anuncia" - passional no sentido de querer conquistar adeptos à causa da unificação da nação italiana.

Enquanto, segundo Althusser (idem), a retórica adequada a ganhar adeptos para a sua causa é o primeiro sentido em que os escritos de Maquiavel podem ser considerados um manifesto, o deslocamento da ideologia do lugar da prática política é o segundo sentido. No âmbito da ideologia, Maquiavel não deveria escrever seu texto do ponto de vista daquele que deve revolucionar a conjuntura histórica: o Príncipe (sujeito da prática política), mas do ponto de vista do povo.

Partindo dessa observação, Althusser procura traçar o elemento que diferencia o Manifesto $\mathrm{Co}$ munista, escrito por Marx, do "manifesto utópico revolucionário", escrito por Maquiavel. De acordo com ele, o Manifesto comunista coloca-se, na ideologia, sob o ponto de vista do proletariado, e é o mesmo proletariado e as demais classes explo-

posição seja incompatível com a defesa do sistema de partido único, uma vez que os partidos subalternos poderiam estar destinados a uma participação minoritária na gestão do Estado, exercendo, de modo apenas marginal, influência sobre o processo de construção do socialismo. Sobre a discussão acerca do pluralismo político socialista, ver Saes (1998b). A segunda ausência dos escritos de Gramsci, que está de algum modo relacionada à anterior, diz respeito, como salienta Lefort (1972), à impossibilidade de discursividade exterior do leitor (poderíamos dizer: da base ou das massas) em relação ao escritor (poderíamos dizer: da direção ou do partido). Segundo Lefort, Gramsci reduz essa relação a uma interpelação. Logo, o discurso que se apresenta inicialmente como aberto, fecha-se, no momento seguinte, não admitindo exterioridade, apenas interioridade discursiva do leitor: “A teoria é reduzida à sua função prática; mas ela conserva o estatuto que lhe confere a tradição idealista: a idéia é transparente nos limites da mensagem. E o intérprete que detém o saber da idéia ignora a necessidade de tomar conhecimento de sua própria prática política” (idem, p. 256). Poderíamos afirmar, assim, que Gramsci, ao conceber o conhecimento como expressão direta da ação política, como ideologia orgânica, parece corroborar a ideologia anticientificista e, conseqüentemente, sugerir que a transformação das ideologias existentes é plausível no plano subjetivo, no plano da ação política organizada, o que o leva a ignorar o papel que cumprem as condições objetivas nessa transformação, ou como nos lembra Marx: os homens agem, fazem história, mas não em condições escolhidas por eles próprios. 
radas que devem se organizar no partido do proletariado, ou seja, é o próprio proletariado que deve ser o sujeito da prática política. Há aqui, portanto, uma coerência entre o ponto de vista de classe definido no texto e o sujeito da prática política, ou ainda, nessa relação, o aspecto ou efeito de alusão da ideologia não abre espaço para o seu contrário: o aspecto ou efeito ilusório. Com os escritos de Maquiavel bastante diferente, uma vez que há um deslocamento entre o lugar ocupado pelo texto e o lugar do sujeito da prática política. Como Althusser (idem, p. 72) observa: "Maquiavel se coloca certamente do ponto de vista do povo, mas esse Príncipe, ao qual é atribuída a missão de unificar a nação italiana, se ele deve se tornar um Príncipe popular, ele não é, de fato, povo. Do mesmo modo, o povo não é chamado a se tornar Príncipe. Há então uma dualidade irredutível entre o lugar do ponto de vista político e o lugar da força e da prática política, entre o 'sujeito' do ponto de vista político, o povo, e o ‘sujeito’ da prática política, o Príncipe.

Essa dualidade existente entre o lugar do ponto de vista político e o lugar da força ou prática política aparece mais explicitamente nos escritos em que Althusser $(1978 ; 1994)$ trata da questão do partido revolucionário, ou ainda, quando ele trata da relação da Internacional Comunista e da organização dos partidos comunistas em relação ao movimento de massas e à própria base partidária.

De acordo com Althusser (1994), o processo de "mundialização" e o "imbricamento dos monopólios”, em curso no último quartel do século XX, teriam criado obstáculos ao modelo de organização partidária, controlado por um centro mundial de decisão e de direção, tal como fora a III Internacional Comunista e por sua relação com os partidos comunistas nacionais. Esse centro mundial de decisão e de direção teria contribuído, durante o século XX, para a divisão das lutas das massas populares, como parecem ilustrar os conflitos entre a URSS e a Iugoslávia de Tito, entre a URSS e a China de Mao, e a ocupação do Camboja pelas tropas nacionalistas do Vietnã (idem). Isso levouo a criticar a idéia de moderno Príncipe, presente em Gramsci, que, segundo Althusser, daria suporte à organização desse centro mundial - diríamos: pouco apegado historicamente à política de autodeterminação dos povos, defendida por Lênin.

No que se refere à organização interna dos partidos comunistas, assim como Gramsci,
Althusser (1978) vê com preocupação a relação entre direção e base, mas aponta para novos problemas, uma vez que entende que os partidos comunistas, em especial o Partido Comunista Francês (PCF), estariam diante de sérias dificuldades de superar um problema estrutural existente em sua organização interna: trata-se do que o autor chama de reprodução do modo de funcionamento burguês da política. Dito de outra maneira: a estrutura e o funcionamento hierárquico do partido passou a reproduzir o aparato de Estado parlamentar burguês, bem como seu aparato militar. No primeiro caso, a vontade política da base do partido transforma-se em poder de direção; no segundo caso, desenvolve-se uma "compartimentagem vertical” do partido, por meio da hierarquização ascendente que existe entre a célula e a seção partidárias, ou ainda, entre a célula e a federação, ou no limite, o comitê central.

Podemos depreender do que foi dito que a crítica à estrutura e ao modo de funcionamento da política burguesa é algo que se revela com maior contundência na análise de Althusser. Em Gramsci, mais do que a crítica à política burguesa, é central a idéia de interpelação dos sujeitos como modo de solucionar o problema da cisão que poderia ocorrer entre partido ou direção, de um lado, e base ou massas populares, de outro.

\section{CONCLUSÕES: TEORIA DA HISTÓRIA E POLÍTICA}

Como já indicamos, é inadequado afirmar que, na definição do conceito de processo histórico, Gramsci e Althusser situem-se no mesmo terreno que Maquiavel. Para este, a história era entendida como movimento cíclico, variando entre a ordem e a desordem, ou melhor, em termos de tempos de duração das formas de convívio entre os homens, uma vez que não haveria como transformar o caráter imutável de certos atributos humanos, tais como: ingratidão, simulação, avidez por dinheiro entre outros.

Em Gramsci, a idéia de natureza humana fixa e imutável não tem lugar: "A recusa de uma natureza humana fixa permitia a Gramsci livrar-se de uma concepção cíclica do tempo sem com isso abrir mão daquela importante sensibilidade histórica” (BIANCHI, 2007, p. 122). Se Gramsci rompe com a definição de história como movimento cíclico, ao mesmo tempo, atribui ao processo histórico um sentido teleológico, visto que acata a idéia de que o "dever ser” encontra-se inscrito no 
"ser”. Trasladando-se essa questão para os problemas da formação social italiana analisada por Maquiavel, entende-se que o povo italiano estivesse subordinado a um destino, um fim, que, mais cedo ou mais tarde, seria atingido. Ou, como sintetiza a fórmula: ainda que a unidade italiana não existisse na época, ela estaria em vias de existir.

Essa visão teleológica da história tem fundamentação, a nosso ver, na tese de que a mudança histórica só tem condições de se consumar caso o desenvolvimento das forças produtivas entre em contradição com as relações de produção existentes e acionem, com isso, uma nova forma política. Nessa perspectiva, não é nas lutas de classes que devemos procurar a possibilidade de fundação da unidade italiana, mas, fundamentalmente, no desenvolvimento das forças produtivas. Nesse sentido, queremos dizer que é possível concluir que está presente nos escritos de Gramsci, mesmo que não sistematizada teoricamente, a idéia de que o processo histórico é determinado pelo desenvolvimento das forças produtivas que, num momento histórico particular (no momento de transição social), entram em contradição com as relações de produção às quais elas davam suporte. Essa mudança na estrutura econômica seria, portanto, pré-condição para a mudança na superestrutura.

Não é por acaso que, ao tomar como problema político a superação do momento dos interesses particulares e a criação do momento dos interesses universais, passasse a adquirir grande influência nas análises de Gramsci do período carcerário o Prefácio de 1859, escrito por Marx. Em especial, a passagem a seguir: "1) A humanidade só se coloca sempre tarefas que pode resolver; a própria tarefa só surge quando as condições materiais de sua resolução já existem ou, pelo menos, já estão em vias de existir; 2) Uma formação social não desaparece antes que se tenham desenvolvido todas as forças produtivas que ela ainda comporta; e novas e superiores relações de produção não tomam o seu lugar antes que as condições materiais de existência destas novas relações já tenham sido geradas no próprio seio da velha sociedade" (GRAMSCI, 1999, p. 140) ${ }^{13}$.

13 Em Marx (1977, p. 27), essa passagem aparece do seguinte modo: “[...] a humanidade só levanta os problemas que é capaz de resolver e assim, numa observação
É certo que na análise da reprodução do todo social, Gramsci opera com a tese de que toda vida social é marcada pela política, pela relação de forças políticas. Contraditoriamente, no entanto, na análise do processo de transição social, sustenta a tese do primado do desenvolvimento das forças produtivas. Desse modo, observa-se que Gramsci apóia-se nessa tese para explicar a transição do feudalismo para o capitalismo na Itália, defendendo que a condição para que a unidade nacional pudesse concretizar-se na Itália estava alicerçada num nível determinado de desenvolvimento das forças produtivas que possibilitasse a constituição de uma nova forma política - poderíamos dizer: no início instável (a monarquia) e, num segundo momento, duradoura (a república)

A partir do que foi dito acima, cabe esclarecer que não nos valemos de uma reflexão global dos Cadernos do cárcere, mas das análises que Gramsci faz do pensamento de Maquiavel. Nesse caso, consideramos que Gramsci parece estar informado, em especial na análise da transição social, por uma visão teleológica da história que se encontra imbricada com a tese do primado das forças produtivas. Se, portanto, as relações políticas incidem sobre a reprodução do todo social, na análise da transição social elas parecem estar subordinadas ao desenvolvimento das forças produtivas, ou ainda, é a mudança econômica que ativa o surgimento de uma nova forma política.

Althusser, nos escritos inéditos, produzidos, ao longo dos anos de 1970 e 1980, aborda a questão do processo histórico sob outro prisma. De acordo com Vatter (2003), na caracterização do processo histórico, Althusser inova em relação à análise de Lefort (1972) ao considerar "a constituição do 'Estado que dura' como uma emergência 'a partir do nada'”. Ou melhor, Althusser concebe esse nada como encontro aleatório do políti-

atenta, descobrir-se-á que o próprio problema só surgiu quando as condições materiais para o resolver já existiam ou estavam, pelo menos, em vias de aparecer. [...] As relações de produção burguesas são a última forma contraditória do processo de produção social, contraditória não no sentido de uma contradição individual, mas de uma contradição que nasce das condições de existência social dos indivíduos. No entanto, as forças produtivas que se desenvolvem no seio da sociedade burguesa, criam ao mesmo tempo as condições materiais para resolver esta contradição. Com esta organização social termina, assim, a pré-história das sociedades humanas”. 
co (virtù) e do social (fortuna), distanciando-se, assim, do discurso das leis da história e da necessidade histórica. Embora Vatter descure da função retórica dos conceitos de nada, vazio, presentes nos textos inéditos ${ }^{14}$, a nosso ver, isso não desautoriza o significado das idéias de contingência e de aleatório, concebidos como possibilidade histórica - no lugar de uma injustificada ausência de determinações ou como processo inevitável e como processo multicausal - em vez de unicausal e de desenvolvimento unidirecional ${ }^{15}$.

Entendemos, portanto, que a crítica radical à visão teleológica da história compreendida como processo inelutável e necessário e o uso do conceito de história compreendido como processo contingente são aspectos elementares e fundamentais que podemos extrair da análise de Althusser. Ademais, é preciso ressaltar que, apesar de efetuar uma autocrítica à sua obra - a qual teria incorrido supostamente no teoricismo, quando das análises elaboradas em Pour Marx e Lire Le Capital -, Althusser não nega a teoria, como sugere Vatter (2003), ou chega a formular nos seus escritos o “materialismo da subjetividade” (NEGRI, 1997), ao supostamente eliminar a distinção entre estrutura jurídico-política (o político) e prática política (a política). Consideramos essas teses inadequadas e infundadas, uma que vez que ignoram o fato de a análise de Althusser ter deslocado o seu objeto de reflexão do patamar dos conceitos "puros" de modo de produção geral e particular - os quais repercutem na análise da reprodução ampliada bem como na análise da transição, tal como aparecem nas reflexões de Balibar -, para o nível do conceito abstrato-formal de formação social na construção da teoria marxista da história. Mais precisamente, afirmamos que esse deslocamento não reduz ao empirismo a teoria da história formulada por Althusser, mas tem o efeito de pôr em evidência os conceitos de lutas de classes e de desenvolvimento desigual.

A análise de Althusser nos escritos inéditos não se reduz ao empirismo, pois o conceito de formação social é compreendido, de modo mais explí-

\footnotetext{
$\overline{14}$ De acordo com Morfino (2006, p. 19): “Se se toma esta função retórica por teórica corre-se o risco de se transfigurar a teoria do encontro em uma teoria do evento ou da liberdade”.

15 Ver observações da nota de rodapé 18.
}

cito, a partir de sua dupla função teórica: como conceito abstrato-formal e como conceito concreto-real ${ }^{16}$. A maioria das análises acerca da produção teórica althusseriana parece descurar da existência dessa primeira função e relegar o conceito de formação social ao âmbito das sociedades concretas. Assim, se na análise de Althusser sobre a obra de Maquiavel, ganha centralidade o conceito de formação social, os adeptos da interpretação empirista da unicidade histórica poderiam argüir que a teoria não existe nessa análise, enquanto os adeptos da "produção em geral" concluiriam que Althusser teria se tornado empirista.

Em nosso entender, o que chama a atenção nos textos inéditos é a formulação do conceito abstrato de formação social, compreendido, de um modo geral, como coexistência complexa de modos de produção, podendo ser pensado quer em sua forma estável ou de duração, quando há a dominância de um modo de produção sobre os demais (coexistência com dominante), quer em sua forma transitória ou instável, quando nenhum modo de produção consegue erguer-se à condição dominante (coexistência sem dominante) ${ }^{17}$. A propósito, o conceito de modo de produção apreendido apenas de modo "puro" abriria brechas para se pensar a transição em termos de desenvolvimento das forças produtivas. Ao contrário, o conceito de modo de produção concebido em estado articulado, isto é, concebido a partir do conceito de formação social, faz realçar o papel determinante das lutas de classes na história, bem como seu desenvolvimento desigual em cada formação social. Tal operação conduz a análise althusseriana a rechaçar a interpretação teleológica da história, pois realiza a crítica sistemática ao modelo explicativo monocausal, enraizado na concepção de modo de produção puro; no sistema binário de classes sociais. Quando se coloca o conceito de formação social no posto de comando, toma o lugar dominante a explicação pluricausal, enraizada na con-

\footnotetext{
16 Embora não concorde com o emprego da primeira função teórica do conceito de formação social acima indicado, Saes (1998a) salienta que a idéia de pensar o conceito de formação social em sua dupla função teórica já havia sido aludida por Étienne Balibar em uma das notas de rodapé do texto Sur les concepts fondamentaux du matérialisme historique.

17 Retiramos de Turchetto (2005) a idéia de forma estável e forma de transição.
} 
cepção de coexistência de modos de produção, na coexistência de mais de duas classes sociais ${ }^{18}$.

Ora, deslocar o objeto de estudo não significa de maneira alguma a negação da teoria. Assim, enfatiza-se a dimensão da coexistência de modos de produção. Isso significa que, ao colocarmos a formulação teórica do conceito de prática política - central em Maquiavel -, não podemos mais concebê-la como efeito de um único modo de produção, mas como efeito da coexistência dos modos de produção com dominante, caso tomemos como objeto de reflexão a reprodução ampliada, e como coexistência sem dominante, a transição.

Enfim, em Gramsci predomina a visão teleológica da história, uma vez que a própria teoria da política subsume-se à sua função prática de construção do momento ético-político. Althusser, ao contrário, refuta a visão teleológica da história, pois ao dar centralidade ao conceito de luta de classes, considera que o processo de transformação social não pode ser tomado como final preestabelecido, mas como produto ou resultado ativo das circunstâncias em que se inscrevem as lutas de classes nas diferentes formações sociais que se desenvolvem desigualmente.

Se há razões explicativas que unem as duas análises da obra de Maquiavel (primeiro sentido da assimilação), há também pontos cruciais que as distinguem (segundo sentido da assimilação). Quanto à convergência, notamos que Gramsci e Althusser não definem teoria da história e política como dois objetos, radical ou absolutamente, distintos. O que significa que a distinção entre esses termos é concebida de maneira relativa. A justificativa para isso se encontra na problemática geral

\footnotetext{
18 Quando falamos em explicação “pluri” ou multicausal remetemos à idéia, já presente em Pour Marx, segundo a qual a contradição capital-trabalho nunca é simples ou absoluta, mas sempre especificada por outras instâncias da vida social ou, como observa Althusser (2005, p. 113; sem grifos no original), "jamais a dialética econômica age em estado puro”. Nos escritos de Althusser, é a noção de sobredeterminação que melhor explica essa idéia de multicausalidade e corrobora a crítica à idéia de contradição única.
}

da qual partem, isto é, ambas as análises têm como preocupação central o processo histórico, não empreendendo, como se poderia supor, uma interpretação humanista que opera com definições como: homem, natureza humana e essência genérica do ser.

Observamos, no entanto, que mesmo concordando quanto ao caráter relativo da distinção entre teoria da história e política, as análises de Gramsci e de Althusser chegam a resultados distintos. Parece-nos possível afirmar que, em Gramsci, essa distinção possui um sentido subjetivo (o que não significa arbitrário), enquanto em Althusser possui um sentido objetivo (o que não é sinônimo de teoria “pura”). Entendemos, assim, que, em Gramsci, a distinção entre teoria da história e política encontra-se em estado prático, ou melhor, não é elaborada teoricamente, uma vez que está subordinada à proposta de ação prática de construção do momento ético-político ${ }^{19}$. Já Althusser toma as reflexões de Gramsci como instrumento teórico que "opera" ou "trabalha" sobre a obra de Maquiavel. Consideramos que o resultado desse processo de elaboração teórica é a construção de uma teoria da história ancorada na ausência de sujeito - o que é sintetizado, por Althusser, na expressão "processo sem sujeito". Isso não significa que a prática política seja despojada de importância, mas que os problemas a serem enfrentados pela prática teórica e pela prática política são distintos. Quanto ao primeiro caso, para o marxismo, coloca-se como imperativo criticar, desconstruir e desvelar as ideologias existentes, inclusive as formuladas em seu próprio arcabouço teórico. Quanto à prática política, apresenta-se um objetivo diferente: o de destruir o Estado e, portanto, o aparelho reprodutor da coesão social. Em nenhum dos dois casos as práticas restringem-se a desconstruir a ideologia e a política dominantes, podendo assumir a função de meras reprodutoras da ideologia e da política dominantes.

19 Nos Cadernos do cárcere, quando Gramsci refere-se à história ético-política tal qual a existente na sociedade burguesa, observamos que, na maioria das vezes, faz uso do recurso de aspas para justamente distingui-la de sua realização plena na "sociedade regulada”.

Danilo Enrico Martuscelli (daniloenrico@yahoo.com.br) é Doutorando em Ciência Política pela Universidade Estadual de Campinas (Unicamp). 


\section{REFERÊNCIAS BIBLIOGRÁFICAS}

ALTHUSSER, L. 1978. Lo que no puede durar en el Partido Comunista. Madrid : Siglo XXI.

1992. O futuro dura muito tempo. São Paulo : Companhia das Letras.

. 1994. Machiavel. In : longtemps. Paris : Stock.

1997. Machiavel et nous. In : L'avenir dure .Écrits philosophiques et politiques. T. II. Paris : Stock.

1998. La solitude de Machiavel. In : SINTOMER, Y. (org.). Solitude de Machiavel. Paris : PUF.

2005. Contradiction et surdétermination. In : . Pour Marx. Paris : La Découverte.

BIANCHI, A. 2007. Laboratório de Gramsci : filosofia e política nos Quaderni del cárcere. São Paulo : s/n.

COUTINHO, C. N. 1999. O partido como "intelectual coletivo". In : Gramsci : um estudo sobre seu pensamento político. Rio de Janeiro : Civilização Brasileira.

2003. O conceito de política nos Cadernos do cárcere. In : COUTINHO, C. N. \& TEIXEIRA, A. P. (orgs.). Ler Gramsci, entender a realidade. Rio de Janeiro : Civilização Brasileira.

FONTANA, B. 1993. Hegemony and Power : On the Relation Between Gramsci and Machiavelli. Minneapolis : University of Minnesota.

GRAMSCI, A. 1999. Cadernos do cárcere. V. 1. Rio de Janeiro : Civilização Brasileira.

2000. Cadernos do cárcere. V. 3. Rio de Janeiro : Civilização Brasileira.

2002. Cadernos do cárcere. V. 5. Rio de Janeiro : Civilização Brasileira.

HOLDEN, A. \& ELDEN, S. 2005. "It Cannot Be a Real Person, a Concrete Individual” : Althusser and Foucault on Machiavelli's Political Technique. Borderlands E-Journal, v. 4, n. 2. Disponível em : http:// www.borderlands.net.au/vol4no2_2005/ eldenhold_foucault.htm. Acesso em : 04.out.2008.
KANOUSSI, D. 2003. Maquiavel nos Cadernos do cárcere. In : COUTINHO, C. N. \& TEIXEIRA, A. P. (orgs.). Ler Gramsci, entender a realidade. Rio de Janeiro : Civilização Brasileira.

LEFORT, C. 1972. Le travail de l'œuvre Machiavel. Paris : Gallimard.

TSÉ-TUNG, M. 1968. Informe sobre una investigación del movimiento campesino en Junan. In : . Obras escogidas. T. I. Pequim : Lenguas Extranjeras.

MAQUIAVEL, N. 2004. O príncipe. Col. "Os pensadores”. São Paulo : Nova Cultural.

MARX, K. 1977. Prefácio. In : __. Contribuição para a crítica da economia política. $5^{\mathrm{a}}$ ed. Lisboa : Estampa.

MORFINO, V. 2006. O primado do encontro sobre a forma. Crítica Marxista, Campinas, n. 23.

NEGRI, T. 1997. Machiavel selon Althusser. Multitudes, Paris, numéro spécial, avr. Lire Althusser aujourd'hui. Disponível em : http:// multitudes.samizdat.net/article1144.html. Acesso em : 3.maio.2008.

SAES, D. 1998a. O impacto da teoria althusseriana da história na vida intelectual brasileira. In : MORAES, J. Q. (org.). História do marxismo no Brasil. V. III. Campinas : UNICAMP.

1998b. O lugar do pluralismo político na democracia socialista. Crítica Marxista, Campinas, n. 6, p. 23-34. Disponível em : http:// www.unicamp.br/cemarx/criticamarxista/ critica6parte3.pdf. Acesso em : 3.maio.2008.

TURCHETTO, M. 2005. As características específicas da transição ao comunismo. In : NAVES, M. B. (org.). Análise marxista e sociedade de transição. Campinas : UNICAMP.

VATTER, M. 2003. Althusser et Machiavel : la politique après la critique de Marx. Multitudes, Paris, n. 13, été. Disponível em : http:// multitudes.samizdat.net/article1107.html. Acesso em : 4.maio.2008. 
GRAMSCI AND ALTHUSSER AS CRITICS OF MACHIAVELLI

\section{Danilo Enrico Martuscelli}

ABSTRACT: This article compares the analyses of Antonio Gramsci and Louis Althusser through a common object of their reflections - the thought of Niccolo Machiavelli. This enables us to present the theory of history that is implicit in each one of these thinkers by: 1 ) showing the elements that provide unity to Gramsci and Althusser's analyses of Machiavelli's work and discussing their interpretations of the latter; 2) presenting the elements of rupture within these analyses and lastly, 3) in our attempt to present a global view of the relationship between Althusser and Gramsci as critics of Machiavelli's thought, we indicate the differences between these authors' theories of history. While Machiavelli had a cyclical view of history, based on his beliefs in human nature, Gramsci refused to put forth any view of "innate nature"; nonetheless, he did hold a teleological view of human history. On the other hand, Althusser, coinciding with Gramsci on the inexistence of any type of “ innate human nature”, was in disagreement with him regarding a teleology of history, preferring a pluri-causal perspective rooted in a conception of the coexistence of modes of production and of more than two social classes.

KEYWORDS: Political Theory; Marxism; class struggle; theory of history; Machiavelli; Gramsci; Althusser.

\section{GRAMSCI ET ALTHUSSER EN CRITIQUES DE MACHIAVEL}

\section{Danilo Enrico Martuscelli}

L'article compare les analyses d'Antonio Gramsci et Louis Althusser à partir d'un objet de réflexion commun - la pensée de Nicolas Machiavel - et présente la théorie de l'histoire implicite liée à tous les deux. Pour accomplir cet objectif, nous effectuons une analyse en trois parties : 1 ) nous présentons les éléments qui unifient les analyses de Machiavel effectuées par Gramsci et Althusser, tout en discutant leurs interprétations de l'oeuvre de Machiavel ;2) nous présentons les élements de rupture entre les analyses de Gramsci et Althusser et, enfin, 3) dans une tentative de présenter un aperçu général de la relation entre Gramsci et Althusser en tant que critiques de la pensée de Machiavel, nous soulignons ce qui sépare ces auteurs en ce qui concerne la théorie de l'histoire. Alors que Machiavel avait une vision cyclique de l'histoire, puisqu'il croyait à une certaine nature humaine, Gramsci refusait la nature innée, bien qu'il ait une vision téléologique de l'histoire, et Althusser, qui est d'accord avec Gramsci quant à l'absence d'une nature humaine innée, s'opposait à ce dernier quant à la conception téléologique et préférait une conception multi-causale, enracinée dans la conception de coexistence de plus de deux classes sociales.

MOTS-CLÉS : Théorie Politique ; marxisme ; lutte de classes ; théorie de l’histoire ; Machiavel ; Gramsci ; Althusser. 